Citation: Gazel, S., The Weak Form Market Efficiency in the MSCI ETF Indices: Conventional And The Fourier Unit Root Test On The Developed And Developing Countries, BMIJ, (2020), 8(4): 409423, doi: http:// dx.doi.org/10.15295/bmij.v8i4.1722

\title{
THE WEAK FORM MARKET EFFICIENCY IN THE MSCI ETF INDICES: CONVENTIONAL AND THE FOURIER UNIT ROOT TEST ON THE DEVELOPED AND DEVELOPING COUNTRIES ${ }^{1}$
}

Sümeyra GAZEL 2

\author{
Received Date (Başvuru Tarihi): \\ Accepted Date (Kabul Tarihi): \\ Published Date (Yayın Tarihi):
}

$17 / 02 / 2020$

$24 / 09 / 2020$

$10 / 12 / 2020$
ABSTRACT

Keywords:

MSCI,

Exchange Traded Funds,

ETF, Fourier,

Weak Form Efficiency

JEL Codes:

G14, G15
In this study, weak form efficiency of the Exchange Traded Funds (ETF) in the Morgan Stanley Capital International (MSCI) Index of developed and developing countries is tested. The Fourier Unit Root test, which does not lose its predictive power in terms of structural break date, number and form, is used on daily data. Also, conventional unit root tests are used for comparison between two different tests. Analysis results indicate common findings in some countries for both unit root testing. However, the Fourier unit root test results relatively more support the assumption of efficient market hypothesis that developed countries may be more efficient than developing countries.

\section{MSCI ETF ENDEKSLERINNDE ZAYIF FORMDA PIYASA ETKINLİĞİ: GELIŞMMIŞ VE GELIŞMEKTE OLAN ÜLKELER ÜZERINE GELENEKSEL VE FOURIER \\ BIRIMM KÖK TESTI}

$\ddot{O Z Z}$

\section{Anahtar Kelimeler:}

$M S C I$,

Borsa Yatırm Fonu,

ETF, Fourier,

Zayıf Formda Etkinlik

\section{JEL Kodlari:}

G14, G15
Bu çalışmada ABD'de Morgan Stanley Stanley Capital International (MSCI) Endeksinde yer alan gelişmiş ve gelişmekte olan ülkelerin Borsa Yatırm Fonlarının (ETF) zayıf formda piyasa etkinliğinin varlı̆̆ sinanmıştır. Hem geleneksel hem de yapısal kırnlma tarihi, sayısı ve formu açısından tahmin gücünü kaybetmeyen Fourier Birim Kök testi günlük verilere uygulanmıştır. Analiz sonuçlarına göre bazı ülkeler için her iki birim kök testi de ortak bulgulara işaret etmektedir. Ancak Fourier birim kök testi sonuçlarının gelişmiş olan ülkelerin gelişmekte olan ülkelere göre daha etkin olabileceğgi varsayımını görece daha fazla destekler nitelikte olduğu tespit edilmiştir.

\footnotetext{
${ }^{1}$ This article is an extended and improved version of the paper published in the proceedings of The 19th International Business Congress hosted by Erciyes University.

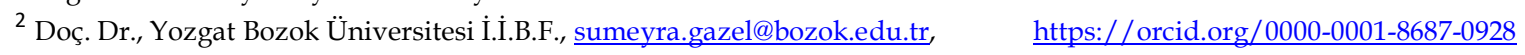




\section{INTRODUCTION}

Capital markets are considered important for economic growth, as they help transform savings into investments in both developed and developing countries. With every financial crisis, the importance of efficient capital markets is better understood. Because capital markets enable economic resources to be directed to production areas. However, this function of capital markets will become more attractive to savers or investors if the stock prices in the market are priced correctly. On the other hand, investors are also in search of profit, and stock prices must be predictable to achieve this goal (Zeren, Kara and Ar1, 2013: 141). At the point of predictability of prices, we encounter market efficiency and a random walk model.

In the decade after the idea of efficient markets emerged, the efficient markets hypothesis has achieved enormous theoretical and experimental success. In addition, quite a lot of experimental findings have been reached to support this hypothesis (Shleifer, 2004: 1). The beginning of the efficient markets hypothesis is attributed to Eugene Fama. Fama (1965) examined the series correlations of daily price changes of 30 stocks traded on the Dow Jones Industrial Average (DJIA) and found that the changes contain very small positive correlations, very close to zero. Based on the results of this study, Fama (1970) made the definition of efficient markets hypothesis as stock prices reflect all available information. In another definition, Malkiel (2003) explains efficient markets as a market in which an investor who does not accept risks above average will not yield above average returns. Fama (1970) evaluates the efficient markets hypothesis under three categories of efficiency. These are weak, semi-strong and strong form effiency. Weak form efficiency refers to future price movements cannot be predicted by looking at past price movements. In other words, in this efficiency, it is assumed that all the information belonging to the previous period is reflected in current prices and that a profit above the average cannot be obtained by looking at the past price data. This kind of efficiency implies that the technical analysis, which is one of the methods used frequently today in predicting the future prices of the stock, will not be valid. Efficiency in semi-strong form refers to the activity where it is not possible to get above the market by using publicly available data. It can be said that "fundamental analysis" is not valid. In an efficient market with a strong form, no 
one, including those who obtain insider information, will be able to obtain a return above the market (Watson and Head 2010: 36). Random walk which a concept that can be evaluated with weak-form efficiency claims that future price steps cannot be predicted by looking past prices. When this concept is adapted to the stock market, it means that the short-term changes in stocks cannot be predicted (Malkiel, 2007: 2). In summary, the future values of the stocks with the characteristic of random walking cannot be predicted based on their past values and this will mean that the market is operating effectively (Al-Jafari, 2011: 15).

In this study, efficiency tests in weak form are carried out based on MSCI ETF indices. MSCI indices were first designed as capital international indices (international capital indices) in 1968 to measure the performance of global capital for markets other than the USA. In 1986, the licenses of international capital indices were taken over by Morgan Stanley and became popular as the MSCI index. Thus, it took its place among the primary indices monitored for markets other than the USA. MSCI indices, which are designed to measure the performance of global capital in the first place, have now been diversified and developed according to many criteria such as MSCI USA Index, MSCI EACWI Index, MSCI World Index, MSCI EAFE Index, MSCI Emerging Market Index (emerging markets index), MSCI Turkey Index (Aydemir, 2016).

ETF is a securities traded on secondary markets, created to track an index. ETF trades with a portfolio of shares that repeat the movements of the index on which it is based. Country ETFs refer to the sub-sector of the ETF market and are designed to track foreign country stock market indices. The privileged feature of country ETFs is that ETF shares and portfolios are traded in two different markets. While ETFs are traded on the New York Stock Exchange, portfolios are traded in ETF's country (Levy \& Lieverman, 2012: 1413).

In this study, firstly, previous studies on this subject are included under the title of literature, and then the Fourier Unit Root test is mentioned in the methodology section. Finally, the results are evaluated by including data and empirical findings. 


\section{LITERATURE REVIEW}

The topic of efficiency is important for both investors, market regulators and governments. Market regulators aim to protect the interests of financial market participants, while investors seek to profit in a well-functioning market. Country governments are aware that they can attract foreign investors in a well-functioning and efficient market. For this reason, the issue of market efficiency emerges as a subject that has attracted the attention of researchers in the literature. Obviously, there are many studies in the literature regarding the determination of efficiency, especially in weak form. Several selected studies are included in this section. The limited number of studies on ETFs are also included in this section.

Rompotis (2011), using parametric and non-parametric tests, examined 66 units ETFs traded in the USA with daily data for the 2001-2010 period. The result shows that ETFs appear to be effective in weak form. Bilbrey, Riley and Sams (2014) investigated the effeciency of 128 units ETFs for the 2007-2012 period with a nonlinear logistic regression model and found that ETFs were not weak form efficient. Saji (2015) analyzed the Indian gold ETF market in terms of efficiency in weak form with daily data for the period 2009-2013. In the study which parametric and nonparametric tests were used it was determined that the efficiency was valid in weak form. Ongere (2020) examined the Nairobi stock exchange ETFs with daily data for the period 2002-2019 and concluded that the efficiency is not valid in weak form.

Saleem and Al-Hares (2018) investigated the efficiency of energy ETFs using daily data. The interval from the date of ETF's listing on the stock exchange to 2017 are taken into consideration. In the study in which the FIGARCH model was used, it was determined that energy ETFs were weak form efficient.

Vaidyanathan and Gali (1994) analyzed the price movements of ten stocks by trading on the Bombay Stock Exchange and found a weak form of efficiency. Choudhry (1994), who studied the weak form efficiency of developed countries (Germany, France, Italy, Japan and Canada) with ADF and KPSS unit root tests, found that markets exhibit a random walk in other words they are efficient. Çelik and Taş (2007) examined market efficiency in weak form in their study which examined 12 
developing countries. According to results, Brazil, South Korea, India, Turkey and Mexico markets were weak form efficient while Czech Republic and Argentina were not weak form efficiency in some periods.

Narayan (2008) determined that G-7 country markets are efficient in weak form by using one and unit root test with two break. Hamid et al. (2010) reached the conclusion that the markets in China, India, Indonesia and Japan are active in a weak form examining 14 Asia-Pacific countries with traditional unit root tests. Hepsağ and Akçalı (2015) tested the efficiency in weak form of G-7 and E-7 countries with asymmetric nonlinear unit root test. The results of the study concluded that the markets in the USA, France, Italy and Japan among the G-7 countries are weakly effective, but the markets of Germany, England and Canada are not.

Zeren et al. (2013) examined the efficiency of the Turkey market with structural break tests The study results show that the BIST 100 index was weak form efficient. Although Zeren et al. (2013) reached an efficient market finding, but it is not possible to mention a single finding in the studies on BIST. While some studies found efficiency in a weak form (Taş and Dursunoğlu, 2004; Atan, Özdemir and Atan, 2009; Karan and Kapusuzoğlu, 2010), some studies found that there was no efficiency (Kahraman and Erkan, 2005; Çevik, 2012; Kaderli, Doğaner and Başkaya, 2017). It is not possible to say that only studies conducted in Turkey have not consensus on the weak form efficiency. The literature shows that the efficiency findings may vary according to the period and method examined.

Unlike other studies, this study examines the weak form efficiency with the Fourier Unit Root Test, which is a method in which the number and form of structural breakage do not affect the test power, based on the Exchange Traded Funds (ETF) in the Morgan Stanley Capital International (MSCI) index of countries in the USA. Accourding to our research, no previous study on weak form efficiency tests based on Fourier unit root test in MSCI index has been encountered. With this aspect of the study, it is expected to contribute to the literature. 


\section{METHODOLOGY}

Whether a market is efficient in weak form is usually determined with the help of unit root tests in the literature. In previous studies on market efficiency, it is seen that traditional unit root tests such as ADF (Dickey and Fuller, 1979), KPSS (Kwiatkowski et al., 1992) and PP (Phillips and Perron) are mostly used. However, these tests are criticized for either ignoring structural changes or considering them in limited numbers.

As it is known, there are many factors that can affect the data especially crises as the time dimension examined increases. In this study, The Fourier KPSS test which developed by Becker et al. (2006) and takes structural breaks into account is used. Although there are many tests that consider structural breakage after traditional unit root tests, Fourier KPSS is not affected the number and form of breakage.

Becker et al. (2006) explained the Fourier KPSS stationarity test with the following process.

$$
\begin{gathered}
y_{t}=x_{t}^{\prime} \beta+Z_{t}^{\prime} \gamma+r_{t}+\varepsilon_{t} \\
r_{t}=r_{t-1}+u_{t}
\end{gathered}
$$

Here, $\varepsilon_{t}, u_{t}$ shows error term and with independent and identically distributed constant variances respectively.

In the equation, $Z_{t}=\left[\sin \left(\frac{2 \pi k t}{T}\right), \cos \left(\frac{2 \pi k t}{T}\right)\right]^{\prime}$ shows the vector containing the trigonometric terms, ' $\mathrm{t}$ ' trend, ' $\mathrm{T}$ ' the sample size and ' $\mathrm{k}$ ' frequency value. Testing whether $y_{t}$ is stable at the level is defined as $X_{t}=[1]$

$H_{0}: \sigma_{u}^{2}=0$ expresses the basic hypothesis of stationarity, and in order to perform this test, equation 2 or equation 3 is estimated and residues are obtained.

$$
\begin{aligned}
& y_{t}=\alpha_{0}+\gamma_{1} \sin \left(\frac{2 \pi k t}{T}\right)+\gamma_{2} \cos \left(\frac{2 \pi k t}{T}\right)+e_{t} \\
& y_{t}=\alpha_{0}+\beta_{t}+\sin \left(\frac{2 \pi k t}{T}\right)+\gamma_{2} \cos \left(\frac{2 \pi k t}{T}\right)+e_{t}
\end{aligned}
$$


Equation (3) tests the level stationary hypothesis, and the model number (4) tests the basic hypothesis of trend stationarity. Test statistics can be tested with the model in equation (5).

$$
\tau_{\mu}(k) \text { or } \tau_{t}(k)=\frac{1}{T^{2}} \frac{\sum_{t=1}^{T} \tilde{S}_{t}(k)^{2}}{\widetilde{\sigma}^{2}}
$$

Here, $\tilde{S}_{t}(k)=\sum_{j=1}^{t} \tilde{e}_{j}$ and $\tilde{e}_{j}$ is the least squares residuals obtained from 3 or 4 Equation.

As in the classical KPSS test, Equation (6) can be achieved by selecting the nonparametric estimated delay parameter $l$ and $w_{j}$ weights $(\mathrm{j}=1,2, \ldots, \mathrm{l})$ of $\sigma$.

$$
\sigma^{2}=\tilde{\alpha}_{0}+2 \sum_{j=1}^{l} w_{j} \tilde{\alpha}_{j}
$$

In Equation (6), $\tilde{\alpha}_{j}$ shows jth sample autocovariance of the residues obtained from equation (3) and equation (4). The value giving the least residual squares sum is used to determine the optimal number of $\mathrm{k}$ (Y1lanc1, 2017).

\section{RESULTS}

In this study, the validity of the weak form efficient market hypothesis is investigated for ETFs, which are included in the Morgan Stanley Capital International (MSCI) indexes of some developed and developing countries and represent the stock market performances of the countries, using daily data.

Australia (EWA), Brazil (EWZ), Canada (EWC), Germany (EWG), Japan (EWJ), Switzerland (EWL), France (EWQ), UK (EWU), South Korea (EWY), South Africa (EZA) ), Turkey (TUR), Chile (ECH), Mexico (EWW), Indonesia (EIDO), Russia (ERUS), India (INDA) and Argentina (ARGT) ETFs are taken into account in analysis. The date range for the analysis is determined as the last 10-year period. Data are obtained from yahoo.finance web site.

Firstly, as the linear unit root tests ADF, PP and KPSS unit root tests are applied and then the Fourier unit root test is performed. The efficiency of the stock market can be investigated by unit root tests. 
If the result of the stagnation is obtained as a result of the test, it is accepted that the market is not efficient in a weak form (Zeren et al., 2013). Table 1 contains the results of the Traditional Unit Root Test.

Table 1. Conventional Unit Root Test Results (with constant)

\begin{tabular}{|c|c|c|c|}
\hline & ADF & PP & KPSS \\
\hline EWA & $-3.36^{* *}$ & $-3.15^{* *}$ & 1.60 \\
\hline EWZ & -1.85 & -1.79 & 4.03 \\
\hline EWC & $-3.00^{* *}$ & $-2.91^{* *}$ & $0.58^{* * *}$ \\
\hline EWG & -2.50 & -2.33 & 2.94 \\
\hline EWJ & -1.45 & -1.29 & 5.21 \\
\hline EWL & -1.05 & -0.80 & 4.65 \\
\hline EWQ & -2.11 & -1.78 & 3.29 \\
\hline EWU & $-3.05^{* *}$ & $-2.72^{*}$ & 0.90 \\
\hline EWY & $-3.21^{* *}$ & $-3.12^{* *}$ & 1.14 \\
\hline EZA & $-3.59^{* * *}$ & $-2.98^{* *}$ & 2.22 \\
\hline TUR & -1.53 & -1.49 & 4.66 \\
\hline ECH & -1.14 & -1.05 & 3.89 \\
\hline EWW & -2.21 & -2.08 & 3.08 \\
\hline EIDO & $-3.47^{* * *}$ & $3.28^{* * *}$ & 1.92 \\
\hline ERUS & -2.01 & -2.08 & 2.89 \\
\hline INDA & -1.84 & -1.63 & 4.21 \\
\hline ARGT & -2.02 & -1.98 & 2.47 \\
\hline
\end{tabular}

***, **, * Indicates significance at $1 \%, 5 \%$ and $10 \%$ levels, respectively. Critical values for ADF and PP Tests are $-3.43,-2.86$ and 2.56 for $1 \%, 5 \%$ and $10 \%$ significance level, respectively. Critical values for the KPSS test are $0.73,0.46,0.34$ for $1 \%, 5 \%$ and $10 \%$ significance level, respectively.

According to Table 1, ADF and PP unit root test results for Australia, Canada, England, South Korea, South Africa, Indonesia show that MSCI ETFs do not contain unit root and are stable at level. In other words, MSCI ETFs of these countries are not effecient in weak form. After the validity of the weak form is tested with traditional linear unit root tests, the Fourier KPSS test which is an expanded adaptation of the KPSS test with trigonometric terms is performed and the results are reported in Table 2. 
Table 2. Fourier KPSS Test Results

\begin{tabular}{|c|c|c|c|c|}
\hline Index & Min. KKT & $\mathrm{k}$ & FKPSS & $\mathrm{F}(\mathrm{k})$ \\
\hline EWA & 8482 & 1 & $0.179^{\star * \star}(40)$ & 647 \\
\hline EWZ & 135300 & 1 & $1.219(40)$ & 3706 \\
\hline EWC & 9493 & 3 & $0.565^{\star * *}(40)$ & 585 \\
\hline EWG & 23030 & 1 & $0.656(40)$ & 688 \\
\hline EWJ & 50959 & 1 & $1.335(40)$ & 1969 \\
\hline EWL & 39173 & 1 & $1.714(40)$ & 700 \\
\hline EWQ & 22091 & 2 & $2.73(40)$ & 591 \\
\hline EWU & 17005 & 1 & $0.343(40)$ & 754 \\
\hline EWY & 77685 & 2 & $0.661(40)$ & 689 \\
\hline EZA & 83718 & 3 & $2.586(40)$ & 731 \\
\hline TUR & 226398 & 1 & $1.141(40)$ & 1313 \\
\hline ECH & 158479 & 1 & $0.982(40)$ & 2988 \\
\hline EWW & 53112 & 1 & $0.177^{* \star *}(40)$ & 680 \\
\hline EIDO & 16753 & 1 & $0.152^{* \star}(39)$ & 3335 \\
\hline ERUS & 48272 & 1 & $0.696(39)$ & 717 \\
\hline INDA & 20794 & 1 & $1.164(34)$ & 2149 \\
\hline ARGT & 22269 & 1 & $0.210^{* * *}(35)$ & \\
\hline
\end{tabular}

$* * *, * *$ denotes the significance at $1 \%$ and $5 \%$ level, respectively. $\mathrm{k}$ indicates the appropriate frequency value selected according to the Principle of Minimum Residue Squares Summation. Critical values for FKPSS test are $0.129,0.170,0.270$ for $10 \%, 5 \%$ and $1 \%$ for the number of observations 1000 when $\mathrm{k}=1$; for $10 \%, 5 \%$ and $1 \%, 0.305,0.404$ and 0.652 respectively when $\mathrm{k}=2$; for $10 \%$, $5 \%$ and $1 \%, 0.3304,0.4388$ and 0.7086 when $\mathrm{k}=3$, respectively. Critical values for the $\mathrm{F}$ test are $3.93,4.65$ and 6.28 for $10 \%, 5 \%$ and $1 \%$ significance level, respectively. Values in parentheses show the bandwidths obtained by the Newey-West Method.

When the results given in Table 2 are evaluated, the $F(k)$ statistical values show that it is significant at $1 \%$ level for Australia (EWA), Canada (EWC), Mexico (EWW), and Argentina, and 5\% for Indonesia (EIDO). It is seen that the FKPSS test statistic value for these countries is smaller than the table value. In this case, ETFs for these countries do not contain unit root, they tend to return to the average. In other words, the weak form efficiency is not valid for these countries, but it is valid for Brazil (EWZ), Germany (EWG), Japan (EWJ), Switzerland (EWL), France (EWQ), England (EWU), South Korea (EWY), South Korea. Africa (EZA), Turkey (TUR), ECH (Chile), Russia (ERUS), India (INDA).

When the traditional and Fourier unit root test results are evaluated together, it is seen that Australia, Canada and Indonesia are not effecient in weak form according to both analysis results. On the other hand, there is a little difference in results between two tests. 
The theory of efficient markets assumes that the volume and depth of the market - the more buyer and seller trading in the market- are important. In this direction, the Fourier Unit root test obtained results closer to the theory with the finding that developing countries are not effective in weak form. Because while the UK ETFs is not efficient in traditional tests, it is efficient in the Fourier approach. Also, according to result of Fourier Tests, country ETFs in highly volatile such as Mexico and Argentina are not efficient.

The graphs in Figure 1 show how well the Fourier functions catch the deviations.
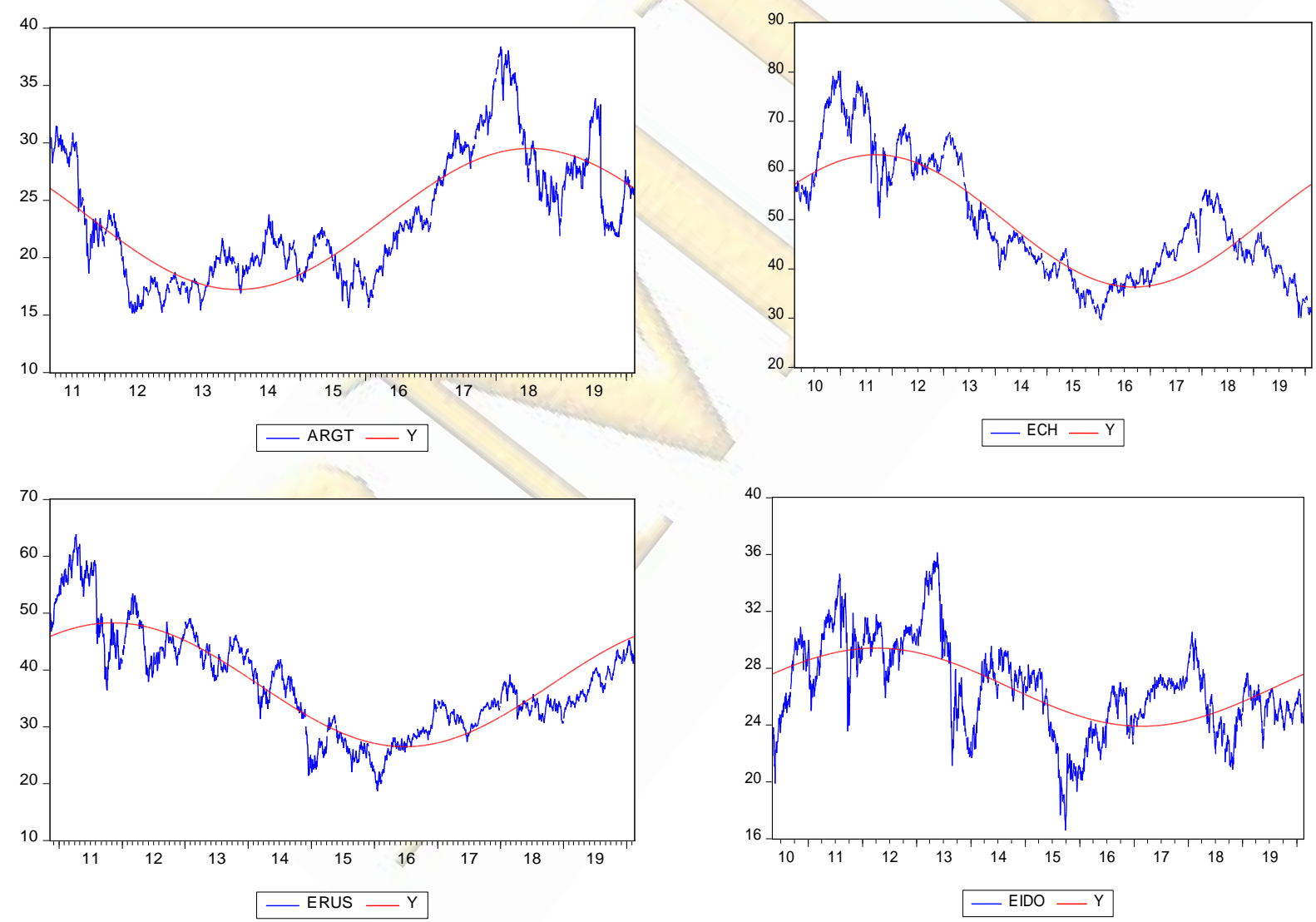

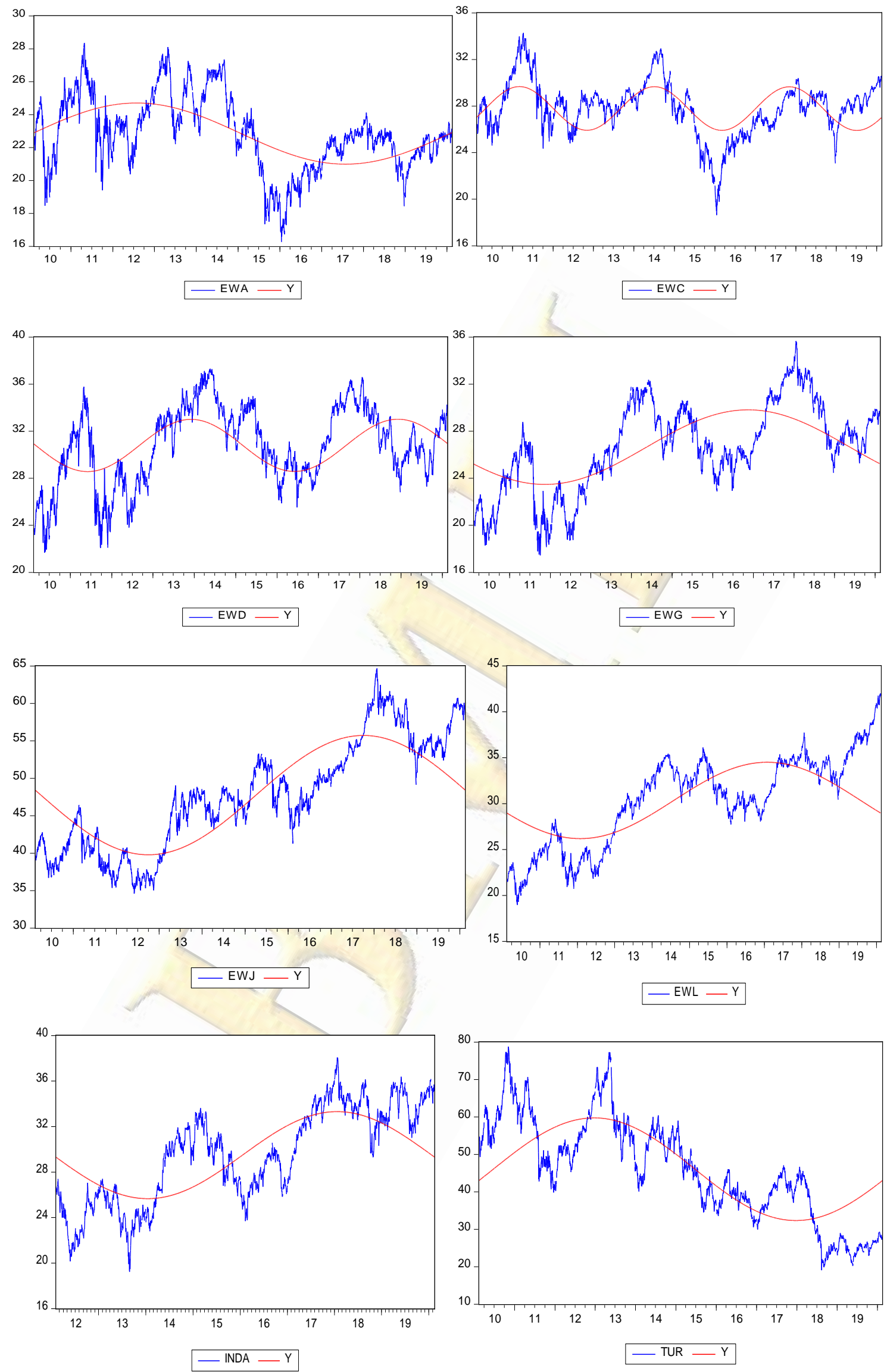

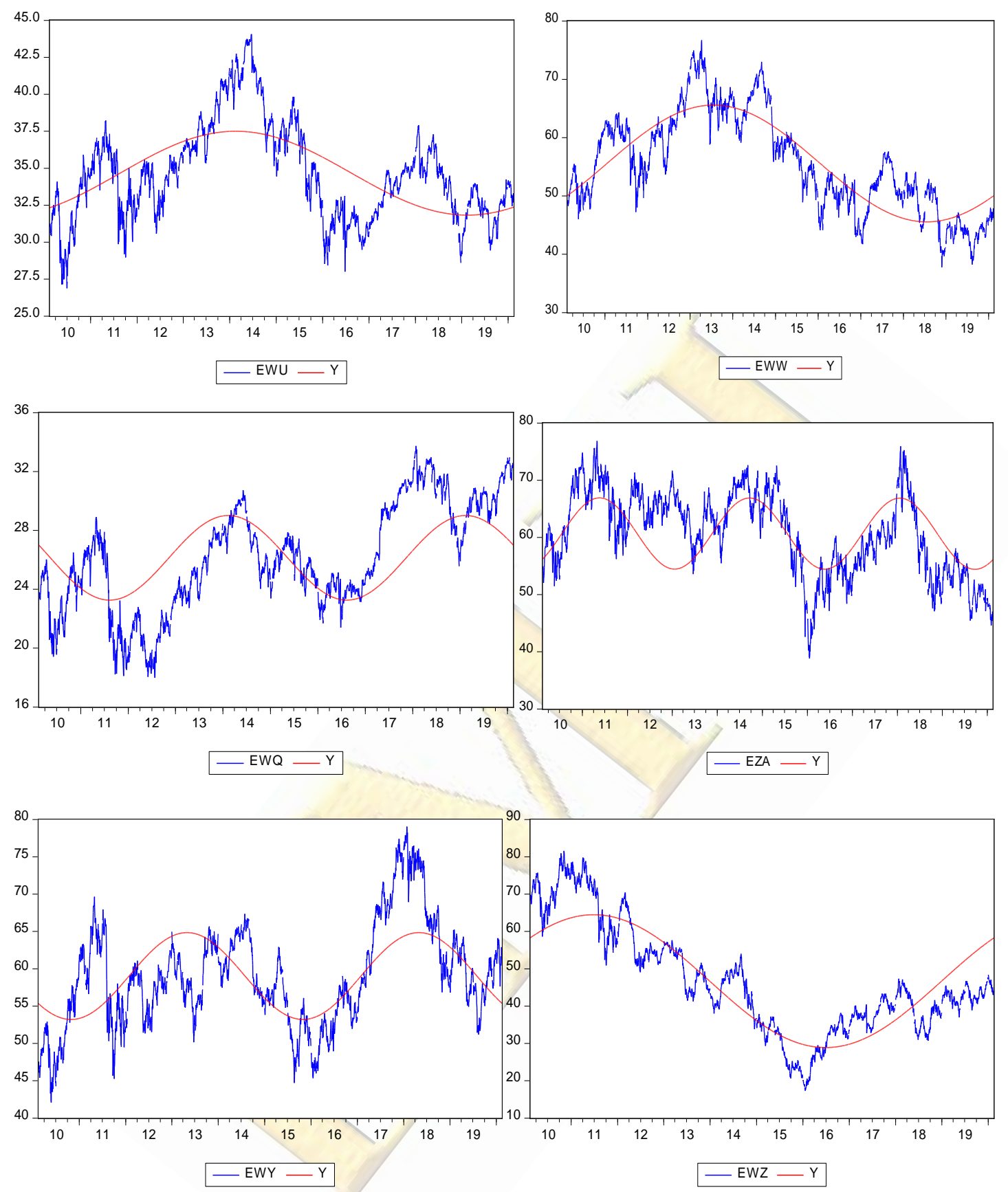

Figure 1. ETFs and Structural Changes

The tests conducted and discussed above show that the series has a unit root for some country ETFs. However, conventional tests assume the series to be linear; such an assumption is quite rigid in many variables in economics. Financial market series in particular are generally non-linear. Therefore, it would be a good way to test the linearity of the series and keep track of progress according to the result (Savaşan et al., 
2015). The above figures show that the nonlinear form and allowing structural changes are necessary to examine the stationarity of ETF series.

\section{CONCLUSION}

Capital markets are of great importance in turning small savings into big investments, ensuring liquidity and determining the prices of securities correctly. It can be said that the more securities are traded in a market and there are large volumes, some of the important criteria for efficiency are fulfilled. However, apart from these criteria, there should also be features related to the speed of information spread in an efficient market. In other words, markets where prices move randomly and investors can access all kinds of information comfortably and costlessly represent efficient markets. Efficiency in financial markets is explained by Efficient Markets Hypothesis.

In this study, unlike other studies, market efficiency in weak form is carried out on country ETFs included in MSCI indices. For most of the series the data of the last 10 years are taken into consideration, but for afew series 8 or 9 years daily data are used since data for the same period could not be obtained in some series,.

Developed and developing countries ETFs are investigated selecting by randomly. In this study that weak form efficiency is tested with unit root tests, a comparison is made between Fourier unit root test approach and traditional unit root tests. According to the traditional unit root test results, it is determined that the MSCI ETFs of Australia, Canada, England, South Korea, South Africa, Indonesia do not contain unit roots and are stable at the level. In other words, the ETFs of these countries in the MSCI index show that the markets are not efficient in a weak form. On the other hand, when the results of the Fourier unit root test are examined, it is determined that ETFs for Australia, Canada, Mexico, Argentina and Indonesia do not contain unit roots and tend to return to the average. In other words, these countries are not in weak form efficiency.

When the traditional and Fourier unit root test results are evaluated together, it is seen that Australia, Canada and Indonesia are not effective in weak form according to both analysis results. A stronger comparison can be made with a larger data set for future studies. 


\section{REFERENCES}

Al-Jafari, M. K. (2011), Testing The Weak-Form Efficiency Of Bahrain Securities Market. International Research Journal Of Finance And Economics, 72, 14-25.

Atan, S. D., Özdemir, Z. A., Atan, M. (2009), Weak Form Efficiency in the Stock Market: An Empirical Study on the ISE, Journal of Dokuz Eylül University Faculty of Economics and Administrative Sciences, 24 (2), 33-48.

Atan, S., D., Özdemir, Z. A., Atan, M. (2009), Weak Form Efficiency in the Stock Market: An Empirical Study on the ISE, Dokuz Eylül University, Journal of the Faculty of Economics and Administrative Sciences, 24, 33-48.

Aydemir, A. (2016), What is the MSCI Index? About MSCI Turkey EFT Index, Access address: https://www.gcmforex.com/egitim/makale-arsivi/msci-endeksi-nedir-msci-turkey-eft-endeksihakkinda

Bilbrey, J.K, Riley, N.F., Sams, C.L. (2014), Short-term prediction of exchange traded funds (ETFs) using logistic regression generated client risk profiles, Journal of Finance and Accountancy

Choudhry, T. (1994), Stochastic Trends And Stock Prices: An International Inquiry. Applied Financial Economics, 4: 383-390.

Çelik, T. T., Taş, O. (2009), Efficient Market Hypothesis and Emerging Stock Markets. ITU Journal, B, $4(2), 11-22$.

Çevik, E. I. (2012), Analysis of Efficient Market Hypothesis in Istanbul Stock Exchange with Long Memory Models: A Sectoral Analysis. Journal of Yaşar University, 7 (26), 4437-4454.

Fama, E. (1965), Random Walks in Stock Market Prices, Financial Analysts Journal, 21 (5) Sept-Oct. Fama, E. (1970), Efficient Capital Markets: A Review of Theory and Empirical Works. The Journal of Finance, 25(2):383-417.

Hamid, K., Suleman, M.T., Shah, S.Z.A. ve Akash, R.S.I. (2010), Testing the Weak form of Efficient Market Hypothesis: Empirical Evidence from Asia-Pacific Markets, International Research Journal of Finance and Economics, 58: 121-133.

Hepsă̆, A., Akçalı, B. Y. (2015), Analysis of Weak Form Market Efficiency Using Asymmetric Nonlinear Unit Root Test: The Case of G-7 and E-7 Countries. BDDK Banking and Financial Markets, 9 (2), 73-90.

Kaderli, Y., Doganer, M., \& Baskaya, H. (2017). Investigation of the Short-Term Effect of New Business Relationship Announcements on Stock Returns of Firms Traded in Borsa Istanbul, Turan: Strategic Research Center, 9 (33), 429.

Kahraman, D., Erkan, M. (2005), Random Walk Test in Istanbul Stock Exchange, Celal Bayar University, İ.İB.F., Journal of Management and Economics, 12 (1), 11 - 24. 
Karan, M. B., Kapusuzoğlu, A. (2010), An Analysis of the Random Walk and Overreaction Hypotheses Through Optimum Portfolios Constructed by the Nonlinear Programming Model, Australian Journal of Basic Application Sciences, 4 (6), 1215-1220.

Levy, A. ve Lieberman, O. (2013), Overreaction of Country ETFs US Market Returns: Intraday vs. Daily Horizons and the Role of Synchronized Trading. Journal of Banking \& Finance, 37, 1412-1421.

Malkiel, B. G. (2003), The Efficient Market Hypothesis and Its Critics, The Journal of Economic Perspectives, 17(1), 59-82.

Malkiel, B. G. (2007), A Random Walk Down Wall Street, W. Norton \& Company: Completely Revised and Updated Edition.

Narayan, P.K. (2008), Do Shocks to G7 Stock Prices Have a Permanent Effect? Evidence from Panel Unit Root Tests with Structural Change. Mathematics and Computers in Simulation, 77(4): 369-373.

Ongere, C. O. (2020), Testing Weak Form of Market Efficiency of Exchange Traded Funds at NSE Market, Mastter Thesis, University of Nairobi School Mathematics,

Rompotis, G. G., Testing weak-form efficiency of exchange traded funds market, aestimatio, The IEB International Journal Of Finance, 2011. 2: 2-33

Saji, T. G. (2015). Weak Form Efficiency of Gold ETF Markets: An Empirical Note from India, Journal of Economic Policy and Research, 10, 1.

Saleem, K., Al-Hares, O. (2018), Measuring the Market Efficiency of Energy Exchange-Traded Funds (ETFs), Theoretical Economics Letters, 8, 1247-1256

Savaşan, F., Yardımcıoğlu, F., Beşel, F. (2015), The Effect of Exogenous Shocks on Particiation on Index of Borsa Istanbul: Parmanent or Temporary?, International Journal of Islamic Economics and Finance Studies, 1 (1), 81-92.

Taş, O., Dursunoğlu, S. (2004), Testing the Activity Level of the ISE with Random Walk Model by Using Dickey-Fuller Unit Root Test Statistics and Runs Test, VII. National Finance Symposium 2004, ITU Faculty of Business, Symposium Proceedings Book, 258 - 269.

Vaidyanathan, R., ve Gali, K. K. (1994), Efficiency of The Indian Capital Market, Indian Journal of Finance and Research, 5(2), 35-38.

Watson, D. ve Head., A. (2010), Corporate Finance Principles and Practise, Financial Times Press.

Yılanc1, V. (2017), Examining the Relationship Between Oil Prices and Economic Growth, Fourier Approach. Istanbul University Journal of Econometrics and Statistics, 27, 51-67.

Zeren, F., Kara, H., Arl, A. (2013), Market Efficiency Hypothesis: An Empirical Analysis for the ISE. Dumlupınar University, Journal of Social Sciences, 36, 141-147. 